\title{
DESCARTU゚V SOUD O KOMENSKÉHO SPISU PANSOPHIAE PRODROMUS
}

Korespondence mezi učenci měla v 17. století (kdy ještě neexistovalo, případně se teprve začalo rozvíjet, odborné časopisectví) daleko větší význam, než tomu bylo v dobách následujících či jak tomu je v přítomnosti. To je důvodem, proč bývají dopisy významných učenců tehdejší doby důležitou součástí jejich odborného díla a bývají z toho důvodu i neodmyslitelnou součástí kritického vydání jejich spisů. Platí to i o vydání dopisů jednoho z nejvýznamnějších myslitelů 17. století, René Descarta. První soubor jeho dopisů, ovšem neúplný, byl vydán již devět let po filosofově smrti. ${ }^{1}$ Ten ovšem musel být postupně doplňován novými nálezy. Dnes je standardní vydání Descartovy korespondence obsaženo v kritickém vydání jeho spisů.

I po tomto vydání dochází, ovšem sporadicky, $\mathrm{k}$ nálezu dalších, předchozí době neznámých dopisů tohoto autora. Nakolik je mi známo, prozatím posledním z nich je dopis objevený r. 2004. Jedná se o jeho posudek (dnes bychom řekli: recenzi) díla českého učence J. A. Komenského Pansophiae Prodromus (Předchůdce vševědy), jež vyšlo tiskem r. 1639 v Londýně. Pansophiae Prodromus obsahuje předběžný náčrt Komenského ideje „pansofie“, tj. stručného, všeobecně dostupného a uspořádaného souboru všeho lidského vědění. Pansofie měla podle záměrů svého autora přispět k položení nových základů věd, a sloužit tak k osvícení lidstva na jeho cestě dějinami. Prodromus vzbudil poměrně značný ohlas a Komenského přátelé a stoupenci, zejména v Anglii působící Samuel Hartlib (cca 1600-1662), jej usilovně širíili v učeneckých kruzích. Tak došlo k tomu, že se Prodromus dostal do rukou vzdělanému leidenskému lékaři Cornelisovi van Hogelande (1590-1662), jenž jej zaslal dále svému př́teli René Descartovi s prosbou o dobrozdání. Descartes odpověděl dopisem, jenž není datován, pochází však zřejmě z konce r. 1639, anebo nejpozději z počátku r. 1640. Posudek Komenského díla, který dopis obsahuje, je sám o sobě významný kulturně historický dokument, pro nás Čechy je pak zvlášt' zajímavý tím, že se týká díla jedné z nejvýznamnějších intelektuálních postav novověkých českých dějin.

Uvedený Descartův posudek o Komenském objevili dva nizozemští historici, Jeroen van de Ven a Erik-Jan Bos, a to v městském archivu

$1 \quad$ Lettres de Monsieur Descartes, vyd. C. Clerselier, Paris 1659. 
v Haagu, v malém souboru listin obsahujícím osobní materiály z pozůstalosti zmíněného lékaře Cornelise van Hogenlande. Oba objevitelé pořídili společně edici tohoto dokumentu, kterou zveřejnili r. 2004. ${ }^{2}$

K Descartovu dopisu téměř není třeba vysvětlujících poznámek. Je tu však přece jedna věc, jež unikla pozornosti obou zasloužilých editorů, ačkoli vysvětlení potřebuje. Vnímavějšímu čtenáři dopisu neujde, že Descartův list prozrazuje přes svou věcnost svým tónem určité autorovo podráždění. Tady ovšem vzniká otázka, odkud toto podráždění pochází? Osobně motivováno být jistě nemohlo, vždyt' Descartes v době, kdy svůj posudek psal, Komenského ještě osobně neznal. Descartova nelibost mohla mít pouze ideový původ. V oboru filosofie nebyl Komenský pro Descarta partnerem (alespoň si to Descartes zřejmě myslel), očekávali bychom proto, že Descartes, pokud se již vůbec odhodlá se Komenského pansofickým projektem zabývat, učiní tak tónem blahosklonně poučným. Takovým tónem je skutečně napsán jeho první dopis (viz pozn. 4) týkající se Komenského díla. Že tomu je ve výše přeloženém dopisu jinak, má svůj původ zřejmě v tom, že Descartes viděl v Komenském sice nerovnorodého, ale - pokud jde o veřejný ohlas - značně úspěšného (v daném okamžiku možná dokonce úspěšnějšího) konkurenta. Jak tomu rozumět?

Komenského pansofický projekt zahrnoval myšlenku nového založení věd, tedy ideu, o níž šlo, jak známo, i Descartovi! Povšimněme si začátku posledního odstavce Descartova dopisu, kde autor upozorňuje, že se snadno může stát, že se najde někdo, kdo položí nové základy věd, někdo, kdo k nim ukáže lidem cestu (= metodu) atd. Koho jiného tu má Descartes na mysli, když mluví o „někom“, než sebe sama? A na co jiného poukazuje Descartes upozorněním (na konci předposledního odstavce), že není záhodno ,věřit učenci, který slibuje nové vědy, jestliže neprokáže, že sám objevil mnoho věcí“, než na skutečnost, že jeho, Descarta, legitimují k jeho smělému plánu reformy věd jeho předchozí vědecké objevy především v oblasti analytické geometrie. Co proti nim lze postavit ze strany Komenského? Podle Descartova mínění nejvýš jeho (Descartovi prý jen z doslechu známé) jazykové př́ručky. At’ je kvalita těchto učebnic sebelepší, nemohou přece tvořit, jak Descartes dotčeně naznačuje, protiváhu k jeho, Descartovu, vědeckému výkonu!

2 Viz český překlad dopisu na str. 107-109 v tomto čísle časopisu.

3 Descartes rozvíjí své myšlenky o novém založení věd a o jeho významu pro lidský život zejména ve své Rozpravě o metodě. 
Dnes víme, že Descartovu koncepci přijalo za své východisko osvícenství a evropská moderna, zatímco Komenského všenápravný projekt si podržel v důsledku svých (i ve své době zdaleka ne běžně přijímaných) theologických principů (požadavek vyvozování profánních věd z biblických principů, theologické odmítnutí karteziánského „,cogito“4, chiliasmus) význam spíše kulturně historický. Z dnešního hlediska neměl Descartes vskutku důvod považovat Komenského za konkurenta.

Co víme dnes, nebylo ovšem stejně jasné na konci třicátých a na počátku čtyřicátých let 17. století, kdy vznikl dopis, jímž se zde zabýváme: v té době Descartes sice již položil základy svého projektu (publikoval již Rozpravu a k ní náležející převážně matematické práce), nezveřejnil však dosud ani Meditace, ani Principy. Mohl tudíž právem cítit obavu, že by recepce jeho filosofie mohla být zdržena úspěchy, jichž v té době dosahoval svými pansofickými vizemi Komenský. Přičteme-li k tomu Descartovo přesvědčení o vlastní vědecké nadřazenosti (nějakou tzv. falešnou skromností Descartes, jak známo, rozhodně netrpěl), máme vše potřebné, abychom porozuměli řevnivosti, jíž dal ve svém dopisu průchod.

Zajímavá je Descartova poznámka na konci jeho listu. Autor zde upozorňuje, že přijetí nového základu lidských věd brání tehdejší školský systém, na jehož změně jeho představitelé nemají osobní zájem (a projevují tedy spíše tendenci zavedený stav věcí bránit). Poznámka má patrně původ v Descartových vlastních zkušenostech. Je známo, že vedle (nesplněné) touhy dosáhnout pro své dílo aprobace Sorbonny usiloval Descartes po určitou dobu také o to, vzbudit zájem o svou myšlenkovou soustavu u jezuitů. ${ }^{5}$ Doufal patrně, že by mocný řád mohl učinit jeho filosofii na svých početných vysokých školách základem výuky. Jezuité se však chovali od počátku k jeho filosofickému úsilí zdrženlivě, později (toho se však již Descartes nedočkal) dokonce odmítavě. ${ }^{6}$

Stanislav Sousedík

4 Toto odmítnutí rozvinul Komenský theologicky zajímavým způsobem ve svém Iudicium de responsione P. Serarii (1667), in: Johannis Amos Comenii Opera omnia, XVIII, vyd. L. Svoboda, Praha 1974, str. 39-56.

5 Viz Euvres de Descartes, vyd. Ch. Adam - P. Tannery, I-XII, Paris 1897-1913, XII, str. 32 .

6 Kateřina Šolcová, překladatelka Descartova dopisu, a Stanislav Sousedík děkují Vladimíru Urbánkovi za upozornění na objev tohoto dokumentu a za laskavé poskytnutí jeho kopie. 